\title{
YESTERDAY, TODAY, FOREVER: Time, Times, Eternity in Biblical Perspective
}

\author{
Henri Blocher
}

\begin{abstract}
Summary
The topic of time and eternity in relation to God is fraught with difficulties. Whatever hints there are from biblical language of Scripture's teaching, they need to be supplemented by a more global and theological use of Scripture. The philological-exegetical arguments for the 'classical'view, which entails the antithesis of time and eternity, go in each case a little beyond what the evidence clearly warrants. Sober considerations prompt us to look for an alternative to pure timelessness, but not to go to the opposite extreme. Scripture witnesses both to God's unchangeable possession of his unbounded life and to the authentic renewal of his grace every morning, a renewal that appears to hold a true meaning for God himself.
\end{abstract}

Calvin, St. Augustine's devotee and putative heir, dared to disapprove of this Master's endeavours on time and eternity: the bishop of Hippo wasted his energy in a 'subtle dispute' that 'does not fit St. Paul's intention'.' What a warning! Especially for one who owes so much to both these spiritual and theological fathers.

The topic is fraught with exceptional difficulties. We find it hard to bring to the fore notions that are so basic that we constantly think through them, and which we always presuppose without reflection. As soon as we start asking what time is, we no longer know, exactly as St. Augustine confessed. ${ }^{2}$ Paradoxes pop up here and there, or even

1 Our translation (as will be the case for the other French works quoted infra) from Commentaires sur le Nouveau Testament (Paris: Ch. Meyrueis, 1854), IV,274, on 2 Tim. 1:9; similarly in IV,317, on Tit. 1:2, Augustine 'inflicts upon himself extraordinary torments' when he tries to understand the phrase 'eternal times'. We have been led to these passages by Olivier Fatio, 'Remarques sur le temps et l'éternité chez Calvin', in Jean-Louis Leuba, ed., Temps et eschatologie: Données bibliques et problématiques contemporaines (Académie internationale des sciences religieuses; Paris: Cerf, 1994), 161.

2 Confessions, XI,xiv, 17: Quid est ergo tempus? Si nemo ex me quaerat, scio; si quaerenti explicare velim, nescio. 
everywhere. Is time moving, or are we moving within time, drifting down the river of time? If it flows, does it flow from the past or from the future? Is the future before or behind us? ${ }^{3}$

For theologians, James Barr pinpointed the main difficulty: 'The very serious shortage within the Bible of the kind of actual statement about "time" or "eternity" which could form a sufficient basis for a Christian philosophical-theological view of time.'4

Yet the stakes are high. Any student who struggles through Karl Barth's Church Dogmatics will come to this realisation; it is an eloquent fact that the perspicacious Barth critic Klaas Runia wrote his doctoral dissertation in 1955 (under Berkouwer's supervision) on 'Theological Time in Karl Barth'. ${ }^{5}$ The issue is relevant to Protestant-Roman Catholic dialogue: at a recent session, as we were discussing prayer for the dead, distinguished Catholic theologians offered us a remarkable argument founded on their view of time and eternity; they proposed that they could pray today for Hitler's conversion before his death in 1945.

For centuries, for more than a millennium and a half, the dominance of what we may call the 'classical' doctrine remained unchallenged. Because most 'doctors' in the church esteemed that it was self-evident-at least to any thinking person - they did not make an effort to build a strong biblical platform to support it. Today, however, the reverse situation obtains, and we cannot simply follow tradition.

Since we are to investigate the matter 'in the open', we should spell out first our presupposition: the doctrinal harmony of $\theta \varepsilon o ́ \pi v \varepsilon v \sigma \tau o \varsigma$ Scripture, on this as on other topics. If Jesus Christ is the same yesterday, today, and forever-and, therefore, beware of 'strange teachings'!- his Spirit, the auctor primarius, is the same today as he was in the days of Moses, and then of Isaiah, and then of Paul. Yet, concepts may vary! Different types of conceptualisation (of viewpoints and schemes) may all be compatible with each other in the service of the one truth. An exploration of that diversity, of the conceptual distinctions between authors and epochs in the Bible, would be a fascinating task, but it would lead us far beyond the scope

3 Some have argued that the Hebrews considered the future to lie behind them, on the basis of the word 'ah $a$ rit (since the root may express being behind); but they also used lipnê 'before' for the same temporal relationship, e.g. Am. 1:1, 'before the earthquake'.

4 Barr, Biblical Words for Time (Studies in Biblical Theology; London: SCM, 1962), 131-32.

5 Runia, De Theologische Tijd bij Karl Barth, Free University of Amsterdam. 
of the present inquiry. It would take too much time: it is one of those singularities that it takes time to think about time; ${ }^{6}$ will it take us eternity to gain some understanding of eternity?

\section{Markers, Clues, Helps, \& Tools on the Way}

In a complex, long-standing, and delicate area of debate, when direct, explicit evidence is lacking, methodological considerations may be decisive. But our remarks do not deserve the title 'On Method' which the needed chapter would bear; they will keep (perforce) a loose and tentative character and only sketch what appears to be of interest to our pursuits.

Lexical and syntactic features of biblical diction were a mine for Oscar Cullmann and his generation. They made much of the use of the same words for time and eternity (as we call them, that is human

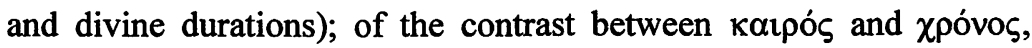
often combined with the antithesis between the Hebrew and Greek minds; sometimes they drew an argument from the priority of the aspectual viewpoint in the conjugation of verbs.

Then came Barr, kešod miššadday! We have been ... debarred from relying on pseudo-linguistics to establish a scientific case. Etymology is no key to semantics; words have many uses that may not be added to one another when we meet a given occurrence; the symmetrical opposition of the Hebrew and the Greek mind-sets leads to an artificial treatment of the evidence. Though controversies have not yet died out among linguists, the idealistic, and often relativistic thesis that binds closely together a specific language and a world-view commands little respect among experts in the field. ${ }^{7}$

On the other hand, it should not be denied that the semantic field of a word offers a kind of condensed memory of what has been said, using that word, on countless occasions. The word remains a convenient peg or knot for opinions. Consequently, the study of the frequent terms one finds in 'talk' on a subject provides a convenient entry into common thinking on the subject. The arbitrary nature of

6 Jean Mouroux, Le Mystère du temps: Approche théologique (coll. Théologie; Paris: Aubier, 1962), 61.

7 The powerful Wilhelm von Humboldt fathered the thesis, and Benjamin Lee Whorf was the loudest advocate in the 20th century (Edward Sapir should not be added to the list, apparently). Apart from the richness of vocabulary, it has proved impossible convincingly to correlate linguistic features and ways of doing and thinking. 
signs, as stressed by Ferdinand de Saussure, does not negate the existence of some relationships between language and the speakers' life (it is not by mere chance that the abundant vocabulary for snow, with many terms for the various qualities of snow, is found among Eskimos, not Tuaregs). Even syntax and declension may allow a glimpse at one way the human mind functions in ordinary experience in its encounter with the world.

Several studies since Cullmann and Barr have canvassed the data. It will suffice if we summarise the conclusions. The main words in Hebrew seem to be ' $\bar{e} t$, both for specific occasions and segments of the process of time, ${ }^{8}$ mô'ed for an appointed time (also $z^{e}$ man, of Aramaic origin) and especially for feasts and sacred days, yôm and yāmîm, which Simon DeVries rightfully emphasised and studied, qedem for high antiquity, as also 'ôläm, very important for remote times, both past and future, and for a whole age, $l^{c} \hat{o} l a \bar{m}$ meaning 'forever, always', in a stronger (infinitely) or in a looser sense (indefinitely); nesah may add the nuance of everlasting validity (from the metaphor of victory? It is doubtful), ' $a d$ of perpetual continuity, as

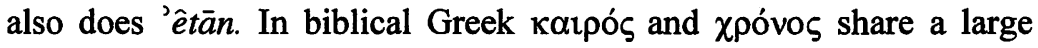
area of common meaning ('times and seasons' should be taken as a hendiadys), and $\alpha \dot{i} \omega \dot{v}$ corresponds well with 'ôläm. There is no clear difference between aiǿvios and the rare aitoros (from the same root

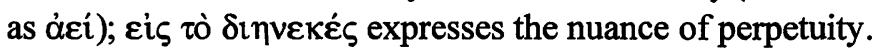

Grosso modo, one may say that time is predominantly mentioned in concrete situations, time for such and such an action, or as a sum of events, but the 'quantitative' interest is strong also: there is a distinct concern for chronology and the measurement of time. Dates abound; let us remember the synchronisms of the Hebrew kings! In Judaism, as the book of Jubilees and the Qumran Rule (1QS IX,12-14) demonstrate, calendar obsession becomes a major component of piety. Why does Stephen insist so much on periods, on measured duration,

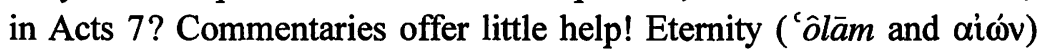
suggests remoteness, fullness, globality, what stands and stays...

The priority of aspects, perfect/imperfect, in the verbal systems of both Hebrew and Greek should not be pressed-there can be an overreaction to older presentations that related the tenses to past, present,

8 Bernard Dupuy, 'Temps et eschatologie dans le judaïsme', in Leuba, Temps et eschatologie, $43 \mathrm{n} .16$ mentions (in respectful terms) the kabbalistic interpretation of ' $\bar{e} t$ and 'et , the accusative particle: the latter is said to be the sign of objectivity and transitivity, the former of subjectivity. 
and future. ${ }^{9}$ Of course, a Frenchman does not forget that he uses the same word temps for 'time' and for 'tense'. At any rate, both Hebrew and Greek offer many other ways (than tenses) of expressing linear succession, chronological before and after. ${ }^{10}$

Paul Ricœur has pioneered another approach based on language, but not on vocabulary or grammar. In an important article, ${ }^{11}$ he starts from literary genres - from 'acts of discourse' (speech-acts, but not in the precise sense of Austin and Searle's theory). The first genre to consider is, obviously, narrative, but Ricœur warns against the illusion of a purely 'narrative theology'; 12 he highlights the original combination with law that renders historical time essentially ethical: stories, 'under the pressure of prescriptive material, become stories of the way of a people with God from the viewpoint [sous le signe] of obedience and disobedience', and Old Testament historiography is largely devoted to an account of Israel's rebellions. ${ }^{13}$ The amalgamation of narrative and law gives foundational events a lasting quality, for they are not just past; the antecedence of law, being beyond recall, saves narrative antecedence from 'vanishing into the "just once" and "never more". ${ }^{14}$ On that basis the people may entertain sure expectations about the future, but prophecy breaks in and cuts through legally-guaranteed yet fallacious assurance: this is effected by the prophecies of woe, which come first, but, then, this reversal is itself reversed by prophecies of weal, or rather of salvation (already Jeremiah and Ezekiel, and above all Deutero-Isaiah). ${ }^{15}$ As to the sense of time, prophecy implies the negative moment and transition, and promotes newness as the future, giving birth to hope and to a new relationship to the past as a treasure of unfulfilled potentialities. Wisdom writings go back to everyday time, the time of daily life, but in union with what is 'immemorial', with the claim of the original position (Pr. 8:2-32); what is immemorial for Job is the condition of humankind, with its border-situations (in Jaspers' sense),

9 K.L. McKay's article, 'Time and Aspect in New Testament Greek', Novum Testamentum 34 (1992) 209-228, appears to strike a balance here.

10 McKay, 'Time and Aspect', 227.

11 Ricœur, 'Temps biblique', Archivio di Filosofia 53 rd year (Padova: Cedam, 1985) 23-35. The contributions of this symposium were made at the 1984 Conference, 'Ebraismo, Ellenesimo, Christianesimo'.

12 Ricœur, 'Temps biblique', 27 and 35, 'the project of a merely narrative theology is a chimera'.

13 Ricœur, 'Temps biblique', 28.

14 Riccur, 'Temps biblique', 28-29.

15 Ricour, 'Temps biblique', 29-31. 
and 'the everyday for Qohelet is the everyday rediscovered by him who has looked straight in the face of death and who has renounced the ambition to know'. ${ }^{16}$ The so-called immemorial dimension meets with ethical antecedence and confers upon events the status of universally valid archetypes (as in the creation stories, nearer to myth than to saga). ${ }^{17}$ All these dimensions hymnic time recapitulates, in the present time of worship and the presence of the everlasting God-'the model of biblical time rests on the polarity of narrative and hymn, on the mediation between "telling a tale" and "praising God" by the law and its temporal antecedence, by prophecy and its eschatological time, by wisdom and its immemorial time.'18 The philosopher's inclinations do show in his selection of elements and his dependence on some historico-critical hypotheses as well; nevertheless, his insights are thought-provoking and sensitive to diversity.

First of all and ultimately, we should find our guiding light in the content of Scripture, rather than its form, linguistic or literary. Though there is little by way of direct, explicit teaching on time and eternity, we should not surrender to pessimism. Some passages at least touch upon the issue and may give us valuable orientation. The first 'tablet' of the Bible, the Prologue of Genesis, bears signs of interest in the topic of time: one cannot ignore the literary choice of the Week as the framework for the creation panorama, the first word berēsit and the work of the fourth day with the role of the luminaries in calendar determination. Does the text intend to teach the creation of time? As a reflection of a divine archetype? Is the apparently unfinished seventh day equivalent to the whole of human history? One meets more than once the meditation on the contrast between the grass-like brevity of man, human life as a vanishing vapour, and the sovereign permanence of God (Pss. 90 and 102, which Heb. 1 uses; in Is. 40 the divine permanence is attributed to the Word, which human beings are called to hear). The Lord's mastery of time and ordering of times is a central claim of the book of Daniel (2:21, cf. 7:12); it is also the great

16 Ricœur, 'Temps biblique', 32-33. On Qohelet, the same symposium includes a very thorough study on 1:4-11, which stresses the influence of Greek popular philosophy, by Norbert Lohfink, 'Die Wiederkehr des immer Gleichen: Eine frühe Synthese zwischen griechischem und jüdischem Weltgefühl in Kohelet 1,4-11', $125-49$, and a stimulating article by Jacques Ellul, 'Le Statut de la philosophie dans Qohelet', 151-64, who defends the integrity and coherence of the whole book and questions the usual ascription of a cyclical view of time to the writer (esp. 159-60).

17 Ricœur, 'Temps biblique', 34.

18 Ricour, 'Temps biblique', 35. The last quotation is in italics in Ricœur's text ('telling a tale' is simply raconter, 'praising God', simply louer). 
presupposition in Isaiah 40ff., when the fulfilment of predictive prophecy is stressed as a powerful apologetic and polemic argument-in 25:1 the theme of the plan of God already surfaces, made long before the events take place. Qohelet, whom we have already mentioned, develops in his own style parallel thoughts on the divine arrangements, with their baffling and humbling diversity, the failure of our attempts at complete systems, and yet the privileged relationship of the human heart to 'olam $(3: 11)$. The function of memory and commemoration looms large in both Testaments. One could also mention the Deuteronomic emphasis on today as the moment of decision 19 or the remarkable phrase about understanding the times (1 Ch. 12:32, cf. Est. 1:13). Micah 5:2 represents another intriguing verse: the origins (môs $\bar{a}^{\prime} \bar{o} t$ ) of the peaceful Ruler from Bethlehem are said to be from of old, miqqedem, from the days of 'ôlām. Eternity? David's time, several centuries before Micah's (as most commentators believe)? Creation (as André Feuillet has suggested, with a specific reference to $\left.\mathrm{Gn} .3: 15^{20}\right)$ ?

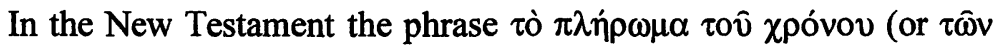

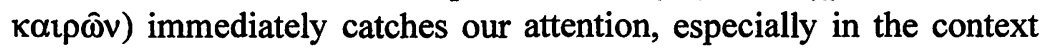
of the Epistle to the Galatians where it follows an argument based on the structure of Old Testament chronological sequence (3:17) and illustrated by the setting of times and delays in a father's last will (4:2). The scheme that governs the relationships between epochs in biblical history provides the basis for typological exegesis, and it is expressed in the remarkable clause: we are those $\varepsilon i \varsigma$ où $\tau \dot{\alpha} \tau \dot{\varepsilon} \lambda \eta \tau \hat{\omega} v$

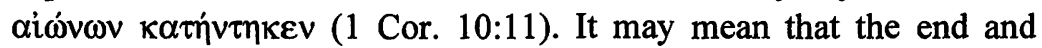
goal of all ages past has dawned with Christ's coming; ${ }^{21}$ it may mean that we stand at the intersection of two worlds, ${ }^{22}$ according to the apocalyptic pattern of the present evil aióv and the coming, salvific

19 Cf. J.G. McConville \& J.G. Millar, Time and Place in Deuteronomy (JSOTSS; Sheffield: Sheffield Academic Press, 1994), 42-43 and passim.

20 Feuillet, Etudes d'exégèse et de théologie bibliques, Ancien Testament (Paris: Gabalda, 1975), 232. This reading is not absent from Jewish tradition: Pesiqta Rabbati 152b interprets: 'King Messiah was born from the origin of the creation of the world', according to Jean Brierre-Narbonne, Les Prophéties de l'Ancien Testament dans la littérature juive (Paris: Librairie orientaliste Paul Geuthner, 1933), 65.

21 Thus Werner de Boor, Der erste Brief des Paulus an die Korinther (Wuppertaler Studienbibel; Wuppertal: R. Brockhaus, 19796), 166, who translates 'die Endziele der Zeitalter'.

22 So Jean Héring, La Première Epitre de saint Paul aux Corinthiens (Commentaire du Nouveau Testament; Neuchâtel: Delachaux \& Niestlé, 19592rev), 81. 
one, a pattern which appears to belong to the conceptual apparatus shared by all New Testament writers. One may add the emphasis (especially in Hebrews) on the once-for-all event, غ̇фár $\alpha \xi$, and such a divine title as 'King of the ages' (1 Tim. 1:17).

We grant that these pieces of evidence, though far from negligible, are not so easy to exploit. There is room for much diversity of interpretation. Whatever hints and indications they yield must be supplemented, therefore, by a more global and theological use of Scripture. Appreciable help comes from the affinities which we may detect between given views of time/eternity and proven components of biblical teaching: some truths of Revelation tend to favour some conceptions and render others less likely. Along that path, one has to renounce a logic of hard and fast demonstration and accept a logic of congruence, pointing to what is fitting and suitable. Such a softer logic makes more room for intuition, and is therefore more vulnerable to subjective distortions; yet Scripture itself, with the ह̌ $\pi \rho \varepsilon \pi \varepsilon v$ of Hebrews 2:10 ('It behoved'), encourages explorers. (We are told that even computer science has grown more and more interested in 'fuzzy' forms of logic!) Arguments gain weight and strength through accumulation.

One should thus consider the relationship of God and world, with the particular position of humankind: most people have considered time and eternity to be the modes of subsisting that belong to the Creator and his creatures. One should ponder the part that history plays in biblical religion, a unique feature as Mircea Eliade (and many others) put in bold relief. ${ }^{23}$

Should we draw on the insights or results of non-biblical philosophy and science? Many snares lie hidden along the road; yet, in principle, since Special Revelation does not occur in a vacuum but presupposes General Revelation (however obscured it may be in its post-lapsarian state), since 'all truth is God's truth', the answer is yes, we should, if we can ... It is of some relevance that a cautious evaluation of the implications of Special and General Relativity makes it difficult to maintain absolute time (at least in the version of

23 E.g. in Le Mythe de l'éternel retour: Archétypes et répétition (coll. Idées; Paris: Gallimard, $1947^{1}, 1969^{\text {new }}$ ) which Eliade wished he could have called 'Introduction to a Philosophy of History', 9; Le Sacré et le profane (Paris: Gallimard, 1965), first published in German in Rowohlts Deutsche Enzyklopädie, 1957; Aspects du mythe (Paris: Gallimard, 1963), first published in English in 1962 (New York: Harper). We refer to other writers in our contribution to H. Blocher \& F. Lovsky, Bible et histoire (coll. Points de repère; Lausanne: Presses Bibliques Universitaires, 1980). 
Newtonian time, the abstract frame of co-ordinates), and also to deny that time is an objective feature of the universe, irreversible (at least, again) at the macroscopic level. ${ }^{24}$ Philosophy is a choir of so many dissenting voices that it is difficult to trust any! Paul Ricour's magnum opus brilliantly brings out the constant double pull of the two decisive references, to the cosmos and to the 'soul', which Aristotle and St. Augustine represent;25 Henri Bourgeois explicitly acknowledges his debt to Ricœur. ${ }^{26}$

Conceding some presumptive advantage to common sense is wise. Daily constraints, born of common needs and intercourse, hold in check the most risky speculations-whereas, in the hothouses of Academia, some plants grow into monsters! It is salutary to remember that Friedrich Christoph Oetinger advocated a new respect for the thinking of everyman: Inquisitio in sensum communem, Heerbrand, 1759. No crushing contempt, therefore, of naïve imaginations of eternity, and no canonisation of the same, either.

\section{Time and Eternity Opposed}

The 'classical' view of eternity, and it entails the antithesis of time and eternity, is summarised in Boethius' magnificent definition: interminabilis vitae tota simul et perfecta possessio, 'the entire, simultaneous and perfect possession of an endless life'. St. Thomas Aquinas not only borrows it but defends it against several possible criticisms. ${ }^{27}$ It is faithful to St. Augustine, who stresses that 'in divine eternity, everything is wholly present, nothing passes' ${ }^{28}$ St. Augustine clings to that understanding; Jean Mouroux quotes from his Enarratio in Psalmos, on divine years that fail not, therefore that

24 Bernard Piettre, Philosophie et science du temps (coll. Que sais-je? Paris: Presses Universitaires de France, 19941, 1996 ${ }^{2}$ ) offers competent summaries, 63-82 (68-69, 82, on irreversibility; 73, affirms a 'universal cosmic time').

25 Ricœur, Temps et récit (3 vols.; Paris: Seuil, 1983-1985), with the recent sequel, La mémoire, l'histoire, l'oubli (Paris: Seuil, 2000), 681 pp.

26 'La Pensée occidentale sur le temps', in Henri Bourgeois, Pierre Gibert, Maurice Jourjon, L'Expérience chrétienne du temps (coll. Cogitatio fidei; Paris: Cerf, 1986), 63; Bourgeois deals more directly with Kierkegaard, 'Lévinias, and Derrida on time than Ricour has done; Bourgeois also does most of the work in the synthesis on Christian temporality, 'Quand les chrétiens prennent le temps de croire', 105-177.

27 Summa theol., $\mathrm{I}^{\mathrm{a}}, \mathrm{Q} .10$, art.1.

28 Confessions, $\mathrm{XI}, \mathrm{xi}, 13$ : Non autem praeterire quicquam in aeterno, sed totum esse praesens. 
remain, therefore are one day, one now. ${ }^{29}$ This nunc stans, pure present, totus simul, appears to be the necessary implication of God's fullness of being: He alone IS (the influence of Ex. 3:14 LXX, o öv, was foundational). It follows from divine immutability, as St. Thomas, especially, underlines. It agrees with the main tendency of Greek philosophical thought, especially the Parmenidian line: for

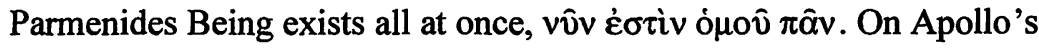
temple the inscription read EI, 'Thou ART'. ${ }^{30}$ As to St. Augustine, his neo-Platonic connection is well-known. ${ }^{31}$

Eternity so conceived contrasts with time. It is practically equivalent to timelessness - and by that word it is designated, ${ }^{32}$ while statements like 'God is outside time', 'God knows no before and after', 'for God there is no past and future', are commonly found. Meister Eckhardt was emphatic: 'Time prevents us from reaching the light. Nothing is more opposed to God than time. Not only time, but attachment to time. Not only attachment, but the mere contact of time. Not only the contact, but the mere scent or taste of time. ${ }^{33}$ Being temporal means lacking being, sliding into nothingness. Time, Xpóvos, is identified with Kpóvos who devours his children:34 Tempus edax rerum, in Ovid's words.

Some thinkers in the classical tradition do make efforts towards a more positive valuation of time. Plato granted time the status of a

29 Mouroux, Le Mystère du temps, 22 (in Ps. 121:6).

30 As Jürgen Moltmann recalled in his Theology of Hope: On the Ground and the Implications of a Christian Eschatology (tr. James W. Leitch; New York: Harper \& Row, 1967), 28. Robert M. Grant, Gods and the One God (Library of Early Christianity; Philadelphia: Westminster, 1986), 79, quotes from Plutarch's treatise On the E at Delphi: 'God exists, if one needs to say so, and he exists for no fixed time but for the everlasting ages which are immovable, timeless, and undeviating, in which there is no earlier or later, no future or past, no older or younger. He being one has completely filled "forever" with one "now"; and being is really being only when it is after his pattern, without having been or about to be, without a beginning and not coming to an end. Therefore in our worship we ought to hail him and address him with the words "Thou art", or even, by Zeus, as some of the ancients did, "Thou art one".'

31 One still refers to Jean Guitton, Le. Temps et l'éternité chez Plotin et saint Augustin (Paris: J. Vrin, 19331 $1971^{4}$ ).

32 Such is the choice of Ronald H. Nash, The Concept of God (Grand Rapids, Mich.: Zondervan, 1983), chapter 6, pp. 73-83, and he characterises the other view by the use of 'everlasting' (God is everlasting rather than timeless).

33 As quoted (with the italics) by Mouroux, Le Mystère du temps, 265 n. 28.

34 Alain Besançon, 'Cronos et Chronos: Note sur la relation au temps de l'histoire', in Enrico Castelli, ed., Herméneutique et eschatologie: La théologie et l'histoire (Rome symposium 1971; Paris: Aubier, 1971), 275-93, who highlights, with psychoanalytical competence, the role of the anxiety of castration and of the archaic cannibalistic mother. 
'mobile image of permanent eternity', ${ }^{35}$ which had, ultimately, to espouse the perfect figure of the circle: the ancients were lost in wonder as they contemplated the cyclic regularity of heavenly bodies, those divine living ones and rulers of time. When St. Augustine interpreted time as essentially bound to the life of the soul, distensio animi, he uncovered a positive feature, at least in our modern eyes. J. Mouroux tries hard to maintain that eternity is the foundation of time as well as its negation. ${ }^{36} \mathrm{Karl}$ Barth goes even so far as to affirm that creation was effected in time, and that God's eternity includes past and future as well as present-yet he really maintains the classical view, since he rules out sequence, the succession of before and after. ${ }^{37}$

The philological-exegetical argument for the classical view concentrates on a few passages which already St. Augustine mustered. ${ }^{38}$ The equivalence for God of a millennium and of a single day (Ps. 90 and 2 Pet. 3) is most impressive for followers of Aristotle, who defined time as the measure of movement (Plotinus criticised him on this count). Psalm 102:25-27 and its quotation by the Epistle to the Hebrews (1:10-12) is brought forward, as is also John 8:58, with its unexpected present tense, as if a past tense was not fit for deity, its majestic I AM that echoes Exodus 3:14.

Scriptural ways of speaking that seem to imply an infinite 'ribbon' of duration, ${ }^{39}$ together with the language of succession, are explained away as inevitable anthropomorphisms, which unfortunately entrap popular imagination. St. Thomas Aquinas recognises here the weakness of our human apprehensio, and he compares with biblical statements on God's 'arms' and 'hands' $40 \mathrm{~J}$. Mouroux expressly deprives the prefix in fore-knowledge, predestination, and the phrase 'before the foundation of the world' of any cognitive value (in respect

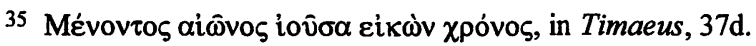

36 Mouroux, Le Mystère du temps, 29, 39, 42, 44, with a sharp perception of the contrast between the Bible on the one hand and the mythical mind and Indian thought on the other, $41 \mathrm{n} .19,48-51,217-20$.

37 Church Dogmatics, III,1, $\$ 41.1$ (esp. 73-74 in the French tr. of F. Ryser, Labor \& Fides, 1960, with a full-length discussion of Augustine's refusal of the clause in tempore); III,2, $\$ 47.1$ and 2 (pp. 122, 124, $217 \mathrm{ff} ., 228$ in the French, 1961). Earlier, in $\mathrm{I}, 2, \$ 14.3$, he could speak of 'a pure presence of God, eternal time, detached from past and future' (p. 108 in the French, 1954).

38 Mouroux, Le Mystère du temps, 16-19, offers an excellent summary of what he sees as the biblical support in favour of the doctrine.

39 A metaphor used by Bruce J. Malina, 'Christ and Time: Swiss or Mediterranean?', $C B Q 51$ (1989) 20.

40 Summa theologiae, $\mathrm{I}^{\mathrm{a}}, \mathrm{Q} .10$, art. 1 ad $4^{\mathrm{m}}$ and 2 ad $4^{\mathrm{m}}$.
} 
to the knowledge of reality as it is in itself): they are only relevant to our feeble representation. ${ }^{41} \mathrm{He}$ quotes St. Gregory of Nyssa to the effect that our minds can only rise to the realisation of their inability to grasp what they seek. ${ }^{42}$

The foregoing considerations do carry some weight. Yet, it seems, not quite enough to make the point. In each case, the conclusion of the argument goes a little beyond what the evidence clearly warrants. That our measurements of time do not apply to God does not require that he be outside temporality. That 'his years' do not come to an end

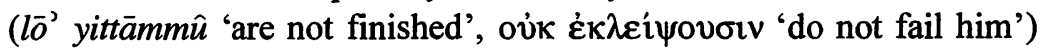
does not entail that there is no before and after in his sight. I AM, in itself, does not exclude 'I was'. The 'classical' comment by Mouroux appears thus to be in excess: 'In God's presence, times are as if they were not. ${ }^{33}$ Is this so?

Scripture, indeed, uses anthropomorphic language; beyond that acknowledgement, I am ready to confess that all 'God-talk' remains analogical. But drawing conclusions and framing them in a univocal conceptual language (if such a language exists!) is a delicate matter. We are free, and obligated, to depart from a naïve-literal understanding of Scripture's 'diction' when Scripture itself indicates that we should do so: it is clear enough for the 'arm' of the Lord and even for his 'repenting', hinnāhèm; and the hermeneutical task remains, then, of appropriating some positive analogical moment. But is there any indication that God's permanence and lordship over the ages rules out the reality of succession for him? In the absence of any distinct encouragement in Scripture itself, it requires a bold move, it involves a perilous step, if one deprives biblical phrases such as 'predestination' or 'before the world began' of most, if not all, of their meaning. It is remarkable that some of the grand proclamations of divine eternity expressly maintain the plurality and order of times, at least in their wording: Jesus Christ the same yesterday, today, and forever (Heb. 13:8); and the counterpart of the unveiling of God's

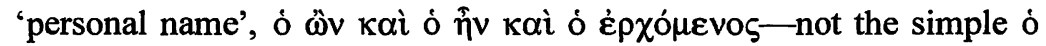

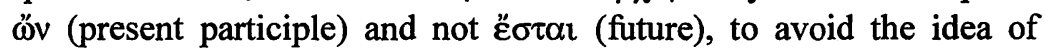
God being still future and not yet realised (Rev. 1:4).

The dogmatic-philosophical argument has been the decisive one. From fullness of being, from immutability and sovereignty, St.

41 Mouroux, Le Mystère du temps, 225 with n. 12.

42 Mouroux, Le Mystère du temps, 23 (the quotation comes from the Contra Eunomium, lib.1).

43 Mouroux, Le Mystère du temps, 18. 
Augustine and those who have followed him, until Mouroux and Paul Helm, ${ }^{44}$ have seen the consequence as so obvious that they have felt free to 'de-anthropomorphise' the ordinary language of Scripture.

We ought to bow before the biblical authority of these themes. Immutability is not first Platonic, it is Scriptural. There is a vibrant witness to that truth, and not only in peripheral passages. ${ }^{45} \mathrm{YHWH}$, no fickle deity, is never taken by surprise: in that sense, there is nothing novel arising before his eyes. Everything is of him, through him, and unto him. That basis of the classical case on eternity, we may not underestimate. The audacious levity with which not a few contemporary theologians dismiss it in a few words is appalling; or is it absent-mindedness?

Yet, and not without fear and trembling, I dare say that I am not convinced. Is there no other way to conceive of divine perfection? Though the classical tradition extols the incomprehensibility of God-not seldom adorned with Neo-Platonic hyperbole, not seldom verging on agnosticism-I cannot get rid of the suspicion that it dictates to God what his immutable perfection must entail. On the top of the metaphysical Everest of concepts like those of being-itself and actus purus, reason may grow dizzy from rarefied oxygen: what is the force of inference? I need more Scriptural explicitness to draw the contours of mystery-lest the mysteriousness of God's mystery become an instrument in our hands.

$\mathrm{J}$. Mouroux is concerned, as we saw, to maintain that eternity is the foundation of time and he knows the contrast with mythical religion. He deserves full credit for his sensitivity and loyalty to the sacred text. But can he do justice to the truth he has perceived? A famous Orthodox theologian-to hear from an author from another tradition-then the dean of the Orthodox Institute of Theology in

44 R. Nash, The Concept of God, singles out Paul Helm as a rigorous defender of the 'timelessness' view and notes, pp. 82-83, that he moved from scepticism about it to strong affirmation. Paul Helm's discussion of the neighbouring topic 'The Impossibility of Divine Passibility', in Nigel M. de S. Cameron, ed., The Power and Weakness of God (Edinburgh Conference 1989; Edinburgh: Rutherford House Books, 1990), 119-40, starts from God's timelessness. As a matter of historical interest, we may add that Calvin, though wary of speculation, did express adherence to the classical position: in his 146th sermon on Job, he preaches that 'Nothing is hidden from God, all things are manifest to him: there is no past time nor time to come in him', as quoted by Richard Stauffer, Dieu, la création, et la Providence dans la prédication de Calvin (coll. Basler und Berner Studien zur hist. und syst. Theol.; Bern, Frankfurt-am-M., Las Vegas: Peter Lang, 1978), 111.

45 I was impressed with this fact when researching for my paper 'Divine Immutability' in the symposium just noted, Cameron, ed., The Power and Weakness of God, 1-22. 
Paris, Serge Boulgakoff, voiced the opposite conviction in no uncertain terms, as he commented on the 'most widespread opinion' that 'for God, time simply does not exist':

First, the Bible-the divine account of God's relations with man, of the divine economy-represents its absolute negation. God's revelation to humanity and all the works of God in the world are represented as occurring in time, for God as well as for man. Considering this merely as an inevitable anthropomorphism, robbing it of its real character, means shattering the whole contents of our faith and transforming God Creator Almighty, living, loving and Saviour, into the motionless Absolute of Hinduism, in which all concrete being is extinguished and the whole world becomes an illusion. ${ }^{46}$

In a less expansive style, the nineteenth century German theologian Isaak Dorner made a similar point, a more flexible understanding of divine immutability must be introduced if history and variety in the world are not to be a semblance but reality and the real effect of God'. ${ }^{47}$ One could shorten the objection: if time does not exist for God, it does not exist. God is the only Measure of truth and reality.

Beware of hard logic in such matters! But if the warnings of Dorner and Boulgakoff are only half-justified, there is already enough ground for serious concern. The classical view of eternity may endanger the consistent reality of time, especially the core and nucleus of historical time, that is irreversible sequence. A conspicuous dimension of the Christian message may be put in jeopardy, for Bruce Malina seems to suffer from myopia when he sees only a resumption of initial conditions in the end of biblical history. ${ }^{48}$ Omega does not equal Alpha! Lactantius showed a keener sense of Christian newness vs. the common 'Mediterranean' depreciation of time, in his polemics against the Stoic writer Lucilius: instead of taking the circular routes of the stars as the evidence of their divinity, he claimed that 'It is evident from this that they are not gods, because it is not permitted

46 Du Verbe incarné (Agnus Dei), vol. I of la Sagesse divine et la théanthropie (tr. Constantin Andronikof; Paris: Aubier, 1943), 54.

47 Dorner, A System of Christian Doctrine (tr. Alfred Cave \& J.S. Banks; Edinburgh: T. \& T. Clark, 1880), I,245. See p. 246: 'If there is a really progressive world and history, God cannot have a relation, which is eternally similar only, to past, present, and future, as though they were one point. If to God a longer or a shorter duration is simply equivalent, upon which matter an inaccurate exegesis of Ps. xc. 4 and 2 Pet. iii.8 has misled,-if "in relation to God one thing is not past, and another present, and another future, but everything collapses into one point in reference to God, into the present" [Philippi II,37,38]-then History is mere appearance, and devoid of valuable result.' This follows a critique of Augustine's dictum.

48 Malina, 'Christ and Time', 20 n. 38. 
them to deviate (exorbitare) from their prescribed orbits. ${ }^{49}$ A decisive reversal! However, not all fruitfully benefited from this insight. History at least partially confirms suspicions. Although most exponents of the classical conception of eternity and time did not carry the logical tendency of their option to the disastrous end, one must note a weakening of the biblical proclamation of the $\dot{\varepsilon} \phi \alpha \dot{\alpha} \alpha \xi$ and newness: in Scotus' (and Osiander's) eternal Christ, ${ }^{50}$ or in Karl Barth's 'Christological concentration' which makes Christ to be the really First Adam, or in Incarnationism generally.

Eternity does provide the foundation of time as the common, unifying reference point, but how can it found the decisive succession? If the 'before and after' relation is radically foreign to God? Ascribing to deity the metaphysical archetype of created features calls for caution indeed; we may not locate in God the duplicate (though considered to be primary, original) of all that we see on earth, here below-certainly not creaturehood! Yet it seems proper to look for the basis, on the Creator's side, of essential positive features of his works, and thus is temporal succession shown to be in biblical perspective.

\section{Time and Eternity Allied}

Sober considerations prompt us to look for an alternative to pure timelessness, but not to go to the opposite extreme. As it has swung away from the classical view, the pendulum, nowadays, has gone too far in the other direction - to a virtual, or even actual, denial of eternity. Oscar Cullmann had already come very near to making God subject to a law of time above him (similar to the Zervan of Persian religion). Process theology openly preaches a pitiful G(g)od, finite and correlative to the world he does not master. Those who wish to grant God the ability to be surprised, or to consummate his own being (unfulfilled, yet) through history, ${ }^{51}$ have to dodge the abundant

49 The Divine Institutes, book II,5, in the Ante-Nicene Christian Library, XXI: The Works of Lactantius I (tr. William Fletcher; Edinburgh: T. \& T. Clark, 1871), 89.

50 Eternal in his human nature also. This Scotist view is popular today, as it suits the attempt to understand Christ's deity in terms of his human nature. Ambiguity helps: the preexistence of the man Christ is affirmed but also qualified as 'ideal', 'in God's foreknowledge or design'; if we could give them their strict sense, these qualifications would bring us back to orthodoxy, but the context shows it is not the case.

51 So does the stimulating theologian Ted Peters, God as Trinity: Relationality and Temporality in Divine Life (Louisville, Ky; Westminster/John Knox, 1993). 
testimony we have already rehearsed. Theirs is an indefensible anthropomorphism, mixed with conformity to a late modern and still romantic inversion of values (Umwertung): the quasi worship of change and novelty.

I am not suggesting that, after all, we sacrifice newness to immutability. On the contrary, I am pleading against that ruinous dilemma. Scripture witnesses both to the Lord's unchangeable possession of his unbounded life and to the authentic renewal of his grace every morning, a renewal that appears to hold a true meaning for God himself.

One window on the mystery of that alliance may open if we consider the unique privilege of the human being. Many writers have discerned that the creature called 'image of God' should not be described as only temporal. In order to be conscious of time, he/she must in some way or other rise above its flow. J. Moltmann highlighted the fact and introduced a telling simile: 'He is like a swimmer moving in the stream of history-or, it may be, against the stream-but with his head out of the water in order to get his bearings and above all to acquire a goal and a future. 52 Even St. Thomas Aquinas affirms that 'the human mind considered in itself is, in a way, above time' and is only subject to time per accidens. ${ }^{53}$

Ecclesiastes' fascinating theologoumenon (3:11) is best understood along that line. 54 'ôläm must have the same meaning as in verse 14 (therefore not 'world', a late meaning, and textual correction is unnecessary); the whole passage embodies a reflection on time. The $2 \times 7$ pairs of opposite actions and passions recapitulate the baffling diversity of the times which God has appointed-man is no more the master of his fate than he is the captain of his soul. It is not the rule of chance, however. There is a hidden beauty (v. 11a) and perfection (v. 14b). And, then, the key element: if man feels baffled, under the 'inyān of verse 10 , it is because he does not undergo passively the succession of diverse times, God has placed in his heart (the organ of thought and consciousness) the 'ôläm-even though the human heart

\footnotetext{
52 Moltmann, The Theology of Hope, 271 [German 249-50].

53 Summa theol., $\mathrm{I}^{\mathrm{a}}-\mathrm{II}^{\mathrm{ae}}, \mathrm{Q} .113$, art.7 ad $5^{\mathrm{m}}$ : Mens autem humana ... secundum se quidem est supra tempus.

54 James Barr, Biblical Words for Time, 117-18 n. 4, comes close to the reading we are suggesting, though he translates 'ôlam 'perpetuity' rather than 'eternity' (the connotations of 'eternity', for his anti-Cullmannian stance, may be near to timelessness). He explains: 'The reference to perpetuity would mean the consciousness of memory, the awareness of past events. The predicament of man is that he has this awareness, and yet cannot work out the total purpose of God.'
} 
rises only partially above the stream and cannot know the whole work of God, the Beauty, from beginning to end.

If this reading does not wander too far from the sense, we may hope to get a glimpse of eternity in our human relationship to time-in our awareness of time and times, in memory, in anticipation and projection, in the synthesis of moments that all this implies. Our sharing in eternity ('oläm) does not involve the abolition of the successive, but a unifying mastery over it, a permanence through it. In human experience, such a mastery and such a permanence are severely limited, far from extending from beginning to end. Is not the suggestion warranted that God's eternity analogically means the unifying mastery, the unalterable permanence, not partial but absolute?

The relationship to projection (always bound to memory) stirs the thought that the succession 'before and after' may derive from action, the ability to act. Maybe the priority of aspects in verbal conjugation could be called to witness here! If there is the power to act, it generates a difference between before (intending, planning to act) and after (the agent has acted), between 'imperfect' and 'perfect'. God's sovereign activity may be seen as the source of a kind of succession in his own life, towards which he is totally active; St. Thomas himself said that we understand eternity more from the viewpoint of activity than of being, secundum operationem, magis quam secundum esse. .5 The human creature is first passive: it undergoes a succession, in the world, which God has determined; but then, as the Image-creature, the human creature is active in turn, having a share in the power to act. May we bring together temporality and passive determination and, then, eternity and active determination?56

The other window would be a comparison with the other, the twin, mystery-of divine Tri-Unity. Some parallel features may be observed, and since the mystery of the Trinity is more fully documented in Scripture and has been more exactly recognised in the Church, some help may come from that 'model'.

Regarding Father, Son, and Holy Spirit, the Church resisted the temptation to sacrifice the One to the Many and the Many to the One,

55 Summa theol., $\mathrm{I}^{\mathrm{a}}, \mathrm{Q} .10$, art.1 ad $2^{\mathrm{m}}$, and the mediating concept is that of life. That paragraph is very significant for our proposal: ...quod est vere aeternum, non solum est ens, sed vivens: et ipsum vivere se extendit quodammodo ad operationem, non autem esse. Processio autem durationis videtur attendi secundum operationem, magis quam secundum esse.

56 This proposal implies that a distinction-not a separation-between God's being and his acts (plural) be accepted, against the tradition of the Actus purus. 
the ruinous dilemma. Likewise, under the blessing of biblical constraints, we strive to think both the unity of the divine life, eternity, and the plurality of succession, together - not the one at the expense of the other. Tradition has admitted a kinship between eternity and oneness, and a kinship between temporality and plurality-with the degradation of time in Neo-Platonic thought interpreted as a fall into the Multiple. Down to Cornelius Van Til, ${ }^{57}$ apologetes have argued that Trinitarian plurality in the Godhead is the foundation of true plurality in creation-a way of reasoning not unlike the one we sketched in favour of succession.

'A $\sigma \nu \gamma \chi v i \tau \omega$, , no confusion, however! If Trinity and eternity are twin mysteries, they are not identical twins! Eternity qualifies the divine essence, which remains numerically one. The only absolute difference in God-the Father is not at all the Son-is the difference of Persons; it is possible because Persons are relations, constitutive, subsisting relations. The same may not be said of past, present, and future. The mystery of divine life as both enduring and active should be approached with other conceptual tools; these may still be in need not only of sharpening or re-shaping, but of invention. Theological orthodoxy has recognised, however, true, 'objective' diversity within the one essence, in ratione sed cum fundamento in re, 58 such as may apply to divine eternity. The astute sixteenth century commentator of the Summa John of Saint-Thomas (Jean Poinsot, 1589-1644) did not hesitate to teach that 'eternity itself is virtually multiple'.59

We should exercise great caution regarding any correlation of

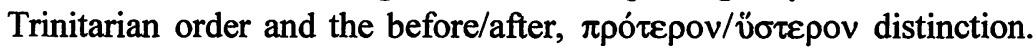
Nathan R. Wood boldly added the analogy of time to the Augustinian list: time is one as God is one, he claimed; at the end, the whole of time will have been future, and present, and past-in that order which

57 Van Til already broached the theme in his 1933 syllabus Metaphysics of Apologetics and came back to it here and there, e.g. An Introduction to Systematic Theology, vol. V of In Defense of the Faith/Biblical Christianity (s.l.: Presbyterian \& Reformed, 1974), 229ff. Cf. Rousas John Rushdoony, 'The One and Many Problem - the Contribution of Van Til', in E.R. Geehan, ed., Jerusalem and Athens: Critical Discussions on the Theology and Apologetics of Cornelius Van Til (s.l.: Presbyterian \& Reformed, 1971), 339-48; Raymond Perron, Cornelius Van Til et sa méthode apologétique (Ph.D. thesis, Faculté de Théologie, Université Laval, Québec, 1993), 78-80, 129-40.

58 André Malet, Personne et amour dans la théologie trinitaire de saint Thomas $d$ 'Aquin (Bibliothèque thomiste; Paris: J. Vrin, 1956), 99, 101 (St. Thomas realised he had to distinguish between id quod and id quo because of Trinitarian theology). 59 Quoted by Mouroux, Le Mystère du temps, 47 n. 39 (In I Iam, X, disp. ix, ad 3, n. 33). 
corresponds to Father, Son, and Holy Spirit. ${ }^{60}$ But did he discern the right order (he denies the filioque)? Though orthodox tradition does suggest that the eternal Trinitarian processions are the foundations of the missions of the Son and of the Spirit, the current confusion of the economic Trinity with the immanent Trinity is anathema to Evangelical theology - the underlying motive, a pernicious one, being the divinisation of the man Jesus quâ man.

In biblical perspective, a mediating term operates between the mystery of God's own eternity, his fullness of being actively renewing itself, and that combination of unity and diversity that obtains in time and between times, historically: the doctrine of God's

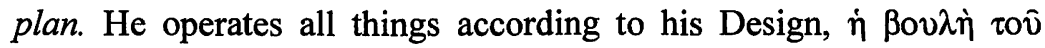

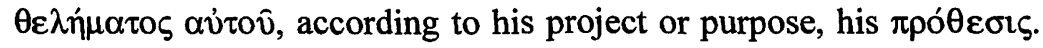
The divine ordering of the temporal field implies two poles: the institution of cosmic rhythms, which probably Paul has in mind in his

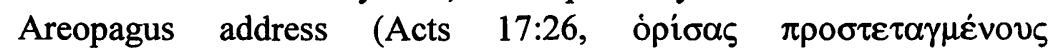
karpov́s)-setting the stage - and the other pole of God's foreordination of events and actual interventions, the plot of the play. As he reflects on the difficult, the unsolved, problem of the unity of time, Paul Ricour comes close to that biblical insight-though he renounces it and prefers an aporetic stance: 'There does not exist a plot of all plots, which could be equal to the idea of one humanity and one history.' 61 In a footnote, he even raises the question of a theology of history, and still denies a 'universal super-plot', with only the argument that we have four Gospels. ${ }^{62}$

The theme of God's antecedent Plan, which looms large in Scripture, is one of the most neglected ones in theology today. It should help us to think through the relationships of time, times, and eternity. But it would not dissolve or dispel mystery, for mystery is indeed involved: God's eternal plan embraces our sharing in eternity, our active determination within God's, so that we may not only wait but also speed the time which the Father has set by his own authority (2 Pet. 3:12).

I deliberately mention last this most enigmatic statement to remind ourselves that we do not know the whole work of God from beginning to end-and should not grieve over the good limitation our wise and gracious eternal God decided to grant us. And so St. Augustine

60 The Secret of the Universe: God, Man and Matter (Grand Rapids, Mich.: Eerdmans, 195510), 20-29, 46-47.

61 Ricœur, Temps et récit, III, 372.

62 Ricœur, Temps et récit, III,372, n. 1. 
himself saw fit to remind his readers, in his concluding words at the end of the eleventh book of his Confessions:

Qui intelligit, confiteatur tibi, et qui non intelligit, confiteatur tibi. $O$ quam excelsus es, et humiles corde sunt domus tua! Tu enim erigis elisos,

et non cadunt, quorum celsitudo tu es.
He who understands, let him bring praises to Thee, and he who does not understand, let him bring praises to Thee. $\mathrm{O}$ how highly uplifted art Thou, and those of humble hearts are thine habitation! For Thou liftest up those who are bowed down, and they fall not, those whose high standing Thou art. 